\title{
Technical and Economic Performance of 1MW Grid-connected PV system in Saudi Arabia
}

\author{
A. F. Almarshoud \\ Department of Electrical Engineering, Qassim University, Buraidah, Saudi Arabia \\ (dr_almarshoud@qec.edu.sa)
}

\begin{abstract}
In this paper, a feasibility study has been done utilizing real time solar irradiance data for a $1 \mathrm{MW}$ grid-connected PV system in Qassim region in the middle of Saudi Arabia. The analysis has been done using both technical and economic indicators. Technical performance indicators are; Yield Factor, Capacity Factor and Performance Ratio. Economic indicators are; Levelized cost of energy and simple payback time. The simulation results show high energy productivity, and both technical and economic indicators are high compared with similar systems in different countries. Also, the greenhouse gas emission reduction has been estimated. The prices of PV modules and balance of system components are up to date. The analysis results proved the viability of the proposed system supposing there is no any governmental incentives or grants which could make big difference..
\end{abstract}

Keywords - photovoltaic; PV; Solar Energy; PV grid-connected; Levelized cost of energy; GHG

$\begin{array}{ll}\text { Abbreviations: } \\ \text { BIPV } & \text { Building Integrated PV system } \\ \text { BOS } & \text { Balance of System } \\ \text { CF } & \text { Capacity Factor } \\ \text { DGPV } & \text { Distributed Generation PV } \\ \text { ECRA } & \text { Electricity \& Cogeneration Regulatory } \\ & \text { Authority } \\ \text { GHG } & \text { Greenhouse Gas } \\ \text { IEA } & \text { International Energy Agency } \\ \text { K.A.CARE } & \text { King Abdullah City for Atomic and } \\ & \text { Renewable Energy } \\ \text { LCC } & \text { Life cycle cost } \\ \text { LCOE } & \text { Levelized cost of energy } \\ \text { MPPT } & \text { Maximum Power Point Tracking } \\ \text { NEEP } & \text { National Energy Efficiency Program } \\ \text { NOCT } & \text { Nominal Operating Cell Temperature } \\ \text { PR } & \text { Performance Ratio } \\ \text { PV } & \text { photovoltaic } \\ \text { PW } & \text { Present worth } \\ \text { SAMA } & \text { Saudi Arabian Monetary Agency } \\ \text { SEEC } & \text { Saudi Energy Efficiency Centre } \\ \text { SPBT } & \text { Simple payback time } \\ \text { STC } & \text { Standard Test Condition } \\ \text { YF } & \text { Yield Factor } \\ \text { Symbols: } & \\ A & \\ C_{\text {capital }} & \text { The capital cost } \\ C_{O \& M} & \text { The operation and maintenance cost } \\ C_{\text {salvage }} & \text { The salvage value } \\ d & \\ E_{A} & \text { Discount rate } \\ E_{\text {grid }} & \text { Energy delivered by the PV array } \\ G_{S T C} & \text { Anergy injected to the grid } \\ & \end{array}$

$G t$

$i$

$K_{t}$

$T_{a}$

$T_{c}$

$T_{r}$

$\alpha_{p}$

$\eta_{i n v}$

$\eta_{p}$

$\eta_{r}$

$\lambda_{c}$

$\lambda_{m}$

$\Sigma G_{t}$

\author{
Global solar irradiance on the plane of \\ PV array \\ Inflation rate \\ Clearness index \\ Ambient temperature \\ Module cell temperature \\ Reference temperature $=25^{\circ} \mathrm{C}$ \\ Temperature coefficient of module \\ efficiency \\ Inverter efficiency \\ Average efficiency of PV array \\ Efficiency of PV module at reference \\ temperature \\ Power conditioning losses \\ Miscellaneous losses of PV array \\ Accumulative irradiance on the plane of \\ $\mathrm{PV}$ array within certain period
}

\section{INTRODUCTION}

The importance of photovoltaic (PV) systems has increased with the rapid growth of solar cells industry over the current and past decades. This is due to the fact that PV systems are clean, environment friendly, and secured energy source. However, the drawback of PV systems is the high capital cost as compared to conventional energy systems

The photovoltaic systems can be classified into two types: Standalone PV system and Gridconnected PV system. Standalone PV system operates independent of the grid and is used to power individual load with batteries storage, while the grid-connected PV system directly feeds the generated power into the grid without batteries storage. Grid-connected PV systems can be divided 
into two types: Building Integrated PV system (BIPV) and Distributed Generation PV (DGPV) system. BIPV systems usually supply a specific load and inject the excess energy to the grid. On the other hand, the DGPV systems inject the whole produced energy to the grid without feeding any local load [1].

PV system size and performance strongly depend on metrological variables such as solar Irradiance, wind speed, ambient temperature. Therefore, to optimize a PV system, extensive studies related to the effect of metrological variables have to be done [2]. The importance of the meteorological data in sizing PV systems lies in the fact that the PV modules output energy strongly depends on the available solar energy and the ambient temperature, Although extreme high temperatures may degrade the performance of some types of photovoltaic modules.

Saudi Arabia has very good conditions for the development of photovoltaic systems due to possessing high daily solar irradiance and sunny days over the year. This indicates that photovoltaic technologies would perform well at any location in Saudi Arabia.

Cost of power from large scale photovoltaic installations reduced to $75 \%$ in the last decade [3]. In Germany, the cost fell from over $40 \mathrm{ct} / \mathrm{kWh}$ in 2005 to $9 \mathrm{ct} / \mathrm{kWh}$ in 2014 . Even lower prices have been reported in sunnier regions of the world, since a major share of cost components is traded on global markets [3] .

The main objective of this paper is to study the viability of $1 \mathrm{MW}$ grid-connected photovoltaic system in Qassim region. Qassim region is located in the center of Saudi Arabia about $350 \mathrm{~km}$ northwest of Riyadh, the capital as shown in Figure 1. Qassim region lies between latitudes $24^{\circ} 41^{\prime} \mathrm{N}$ and $27^{\circ} 19^{\prime} \mathrm{N}$ and longitudes $41^{\circ} 38^{\prime} \mathrm{E}$ and $44^{\circ} 50^{\prime} \mathrm{E}$, which is in the solar belt, and the elevation is $600-750 \mathrm{~m}$ above the sea level. The climatic condition of Qassim region is a typical desert climate, known for its cold, rainy winters, and for its hot and sometimes balmy summers, with low humidity and dusty sometimes [4] . The average daily solar irradiance in Qassim is $6.13 \mathrm{kWh} / \mathrm{m} 2 /$ day and has a long daily duration of sunshine [5]. Figure 2 shows the average annual sum of global horizontal irradiance in Saudi Arabia [6] . Therefore, the use of PV systems in Qassim region has a very good potential.

In this paper, a technical and economic analysis for evaluating the feasibility of $1 \mathrm{MW}$ grid-connected PV system in Qassim region has been presented based on both technical and economic indicators. Technical performance indicators are Yield Factor, Capacity Factor and Performance Ratio while, economic indicators are Levelized cost of energy and simple payback time. This work is based on one-minute meteorological data provided by King Abdullah City for Atomic and Renewable Energy (K.A.CARE) recorded by the meteorological station hosted in Qassim University. Finally, a comparison of the obtained results with similar PV grid-connected systems in different countries will be presented.

\section{SOLAR ENERGY POTENTIAL IN QASSIM REGION}

A real one-minute meteorological data for the last two years recorded by the meteorological station in Qassim University. The recorded data was global horizontal irradiance, direct normal irradiance, diffuse irradiance, ambient temperature, humidity, atmospheric pressure and wind speed. Figure 3 shows a sample of recorded solar irradiance for one day. Figures 2 and 3 indicate that Qassim region is a promised region for solar energy applications, but the average of ambient temperature which reaches $37^{\circ} \mathrm{C}$ in summer would reduce the overall efficiency of PV system, as an increase in cell temperature by $1^{\circ} \mathrm{C}$ decreases PV module's power by $0.5-0.6 \%$ [7]. This means the expected output power of PV modules will be lower than mentioned in their data sheets because, the PV modules are being tested at $25^{\circ} \mathrm{C}$.

\section{BOUNDARIES OF THIS STUDY}

Along with solar radiation, other factors which may affect this study are : type of PV technology deployed, Fixed or with sun tracker, tilt and azimuth angles of PV modules, inverter efficiency, utilizing the Maximum Power Point Tracking system (MPPT) or not. Further, economical parameters such as interest rate, discount rate, inflation rate prevalent and projected in Saudi Arabia, percentage of debt to the initial capital cost of the whole project also plays critical role.

This study will be based on the following:

i. The PV technology is mono crystalline silicon, ground-mounted modules, fixed tilt angle equals to location latitude, south facing azimuth angle.

ii. Inverter equipped with MPPT system.

iii. The economic parameters as provided by the Saudi Arabian Monetary Agency (SAMA) in 2015 [8] .

iv. The percentage of debt of the capital cost is $(0 \%)$, and there is no any Incentives or grants.

v. The life time of project is 25 years..

\section{MATHEMATICAL MODEL OF GRID- CONNECTED PV SYSTEM}

Figure 4 shows a typical PV grid-connected system consisting of a PV array, inverter and a connection to the grid. So the mathematical model of the PV grid-connected system will combine both models of PV array and the inverter. The 
instantaneous output power of a PV array depends on the global solar irradiance on the plane of PV array; Gt , and the ambient temperature; Tc. The influences of these two parameters on the cell characteristics are shown in Figure 5, where the open circuit voltage increases logarithmically by increasing the solar irradiance and the short circuit current increases linearly as shown in Figure 5a, while the main effect of increasing in cell temperature is on open circuit voltage, which decreases linearly with the cell temperature and the short-circuit current increases slightly with the increase of the cell temperature as shown in Figure 5b. Thus, the cell efficiency will drop [9]. This frequent change in the cell characteristic leads to frequent change in the position of maximum power point as shown in Figure 6. So, for achieving the maximum output power from the PV array, an inverter equipped with MPPT system is preferred. Therefore, the assumption in this model is that the PV array only generates power at the maximum power point on the I-V curve [10] .

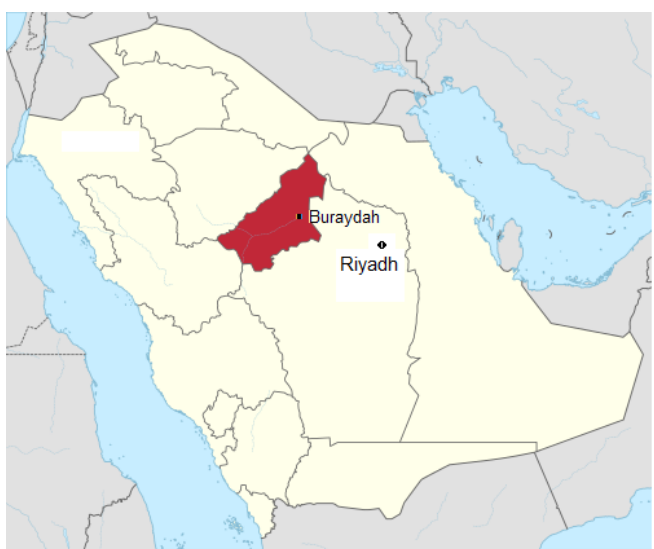

Fig. 1: Location of Qassim Region in the middle of Saudi Arabia

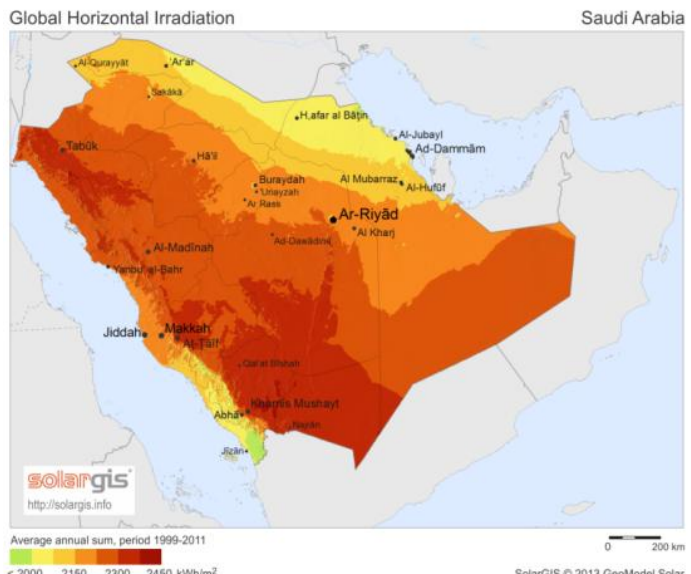

Fig 2: The Average annual sum of global horizontal irradiance in Saudi Arabia

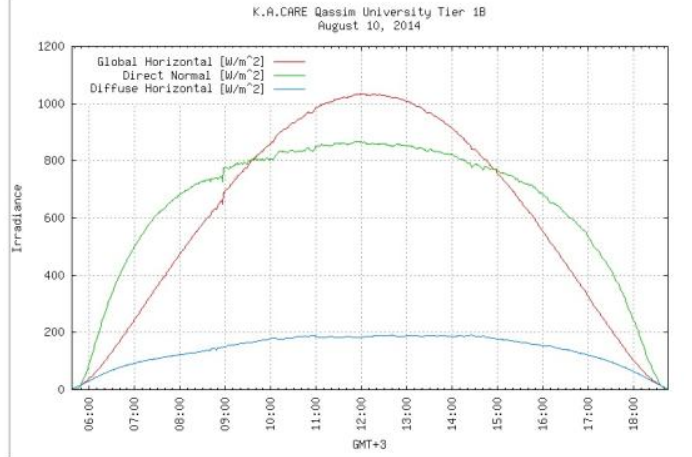

Fig. 3: Sample of recorded solar irradiance data on August 10, 2014

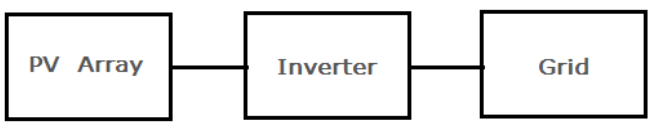

Fig. 4: Block diagram of grid-connected PV system
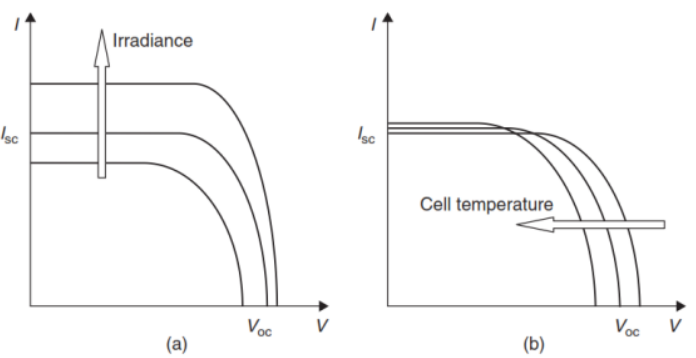

Fig. 5: Influence of irradiation and cell temperature on PV cell characteristics.

(a) solar radiation effect, (b) cell temperature effect.

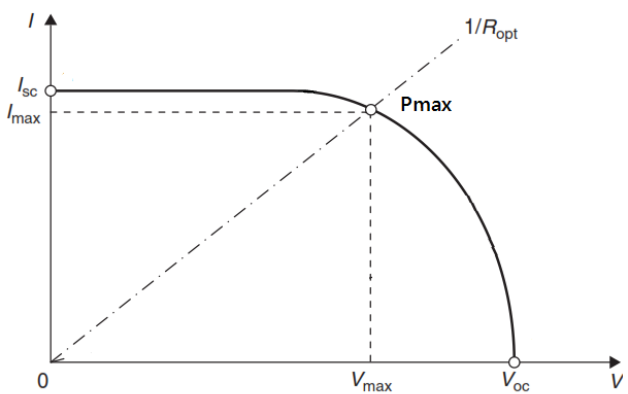

Fig. 6: Position of the maximum power point on I-V characteristic of PV cell

\section{A. Energy delivered by the PV array}

The array is characterized by its average efficiency, $\eta_{p}$, which is a function of average module cell temperature, $\mathrm{T}_{\mathrm{c}}$ [10], [11]:

$\eta_{P}=\eta_{r}\left[1-\alpha_{p}\left(T_{c}-T_{r}\right)\right]$

where $\boldsymbol{\eta}_{\boldsymbol{r}}$ is the PV module efficiency at reference temperature $\boldsymbol{T}_{r}$, and $\boldsymbol{\alpha}_{\boldsymbol{p}}$ is the temperature coefficient for module efficiency. $\boldsymbol{T}_{\boldsymbol{c}}$ is related to the mean ambient temperature, $\boldsymbol{T}_{\boldsymbol{a}}$ as following [10], [11]: 
$\mathrm{T}_{\mathrm{c}}-\mathrm{T}_{\mathrm{a}}=\frac{219+832 \mathrm{~K}_{\mathrm{t}}}{800}(\mathrm{NOCT}-20)$

where NOCT is the Nominal Operating Cell Temperature and $\boldsymbol{K}_{\boldsymbol{t}}$ is the clearness index.

The energy delivered by the PV array $\boldsymbol{E}_{\boldsymbol{A}}$ is [11]:

$E_{A}=n_{p} A G_{t}\left(1-\lambda_{m}\right)\left(1-\lambda_{c}\right)$

where $\boldsymbol{A}$ is the area of the PV array, $\lambda_{m}$ and $\lambda_{c}$ are the miscellaneous losses of PV array and power conditioning losses respectively.

\section{B. Energy injected to the grid}

The grid-connected model is so simple as shown in Figure 4, where no load is attached. So the energy injected to the grid is equal to the energy produced by the PV array reduced by inverter losses as following:

$$
E_{\text {grid }}=E_{A} \cdot \eta_{\text {inv }}
$$

where $\eta_{i n v}$ is the inverter efficiency

\section{PERFORMANCE INDICATORS OF GRID-CONNECTED PV SYSTEM}

The feasibility of a grid-connected PV system must be determined using both technical and economic performance indicators. Regarding the technical performance indicators, The International Energy Agency (IEA) photovoltaic power systems program suggested some indicators for evaluating the performance of PV system. These indicators include the total energy yield, the yield factor, the capacity factor and the performance ratio. These technical indicators help in comparison between similar PV systems to determine which works better. On the other hand, the economic indicators are the levelized cost of energy and the simple payback time.

The total energy yield is the total amount of energy that is injected into the grid. The yield factor (YF) measures the productivity of a PV array under certain weather condition, and it is defined as the annual, monthly, or daily net AC energy output of the system divided by the peak power of the installed PV array at standard test condition (STC) and it is given by [12].

$\left.\mathrm{YF}=\frac{\mathrm{E}_{\text {grid }}(\mathrm{kWh} / \text { year })}{\mathrm{PV}_{\text {array }}(\mathrm{kW} \text { peak }}\right)$

The capacity factor (CF) measures the percentage of usability of PV array, and it is defined as the ratio of the actual annual energy output to the amount of energy the PV array would generate if it is operated at full rated power for 24 hour per day for a year, because the sun is only available for 12 hours a day, so the ideal $\mathrm{CF}$ will be $50 \%$ due to the unavailability of sun during the night. The typical value of $\mathrm{CF}$ usually is less than $40 \%$ for most regions in the world due to energy conversion losses and weather change, and it is given by [12]:

$$
\begin{aligned}
& C F=\frac{E_{\text {grid }}(\mathrm{kWh} / \text { year })}{\left(8760 * \mathrm{PV}_{\text {array }}\left(\mathrm{kW}_{\text {peak }}\right)\right)} \\
& C F=\frac{\boldsymbol{Y F}}{\mathbf{8 7 6 0}}
\end{aligned}
$$

Performance ratio (PR) is defined as the actual amount of PV energy delivered to the grid in a given period divided by the theoretical amount according to STC data of the modules [13]. It is independent of location and system size and indicates the overall effect of losses on the array's nominal power due to: inverter inefficiency, wiring mismatch, other losses when converting from d.c. to a.c. power, PV module temperature, incomplete use of irradiance, soiling or snow, system down-time, and component failures [14], [15].

$P R=Y F \cdot G_{S T C} / \sum G_{t}$

Where $\mathrm{G}_{\text {STC }}$ is amount of irradiance at STC, and $\Sigma \mathrm{G}_{\mathrm{t}}$ is the accumulative irradiance on the plane of PV array within certain period (annual, monthly, or daily).

The levelized cost of energy (LCOE) is the average cost of energy produced $(\$ / \mathrm{kWh})$ over the life time of project, i.e., the life cycle cost (LCC) of project divided by the expected output of energy during the project life time. LCC is the sum of all costs associated with an energy delivery system over its lifetime in today's money, taking into account the time value of money [9]. The purpose of using the LCC is to bring back costs that are anticipated in the future to present day costs by discounting, i.e., by calculating how much would have to be invested at a market discount rate [9]. The life cycle cost is given by [16]:

$L C C=C_{\text {capital }}+\Sigma \mathrm{C}_{\mathrm{O} \& \mathrm{M}}+\Sigma \mathrm{C}_{\text {replacement }}-\mathrm{C}_{\text {salvage }}$

The capital cost $\left(\mathrm{C}_{\text {capital }}\right)$ of a project includes the initial expense for equipment, the system design, engineering, and installation. This cost is always considered as a single payment occurring in the initial year of the project. The operation and maintenance cost $\left(\mathrm{C}_{\mathrm{O} \& \mathrm{M}}\right)$ is the sum of all yearly scheduled operation and maintenance costs. Replacement cost is the sum of all spare parts and equipment replacement cost anticipated over the life of the project, for example the replacement of inverter after 15 years. The salvage value $\left(\mathrm{C}_{\text {salvage }}\right)$ of a project is its value in the end of the life cycle period. All these anticipated costs should be discounted to their present worth taking into account inflation rate (i) and discount rate (d). The present worth (PW) for any future cost is given by [9]:

$$
P W_{n}=\frac{C(1+i)^{n-1}}{(1+d)^{n}}
$$

where $(\mathrm{n})$ is the number of years.

After calculating the life cycle cost, the levelized cost of energy can be calculated by 
dividing the life cycle cost of project by the expected output energy during the project life time as follows [17]:

$$
L C O E=L C C / \Sigma E_{\text {grid }}
$$

The simple payback time (SPBT) is one of the most requested measures of a renewable energy system's economic feasibility. Simple payback time determines the number of years for the energy savings from a renewable energy system to offset the initial cost of the investment and given by [18]:

$S P B T($ years $)=\frac{\text { Initial Cost }(\$)}{\left(E_{\text {grid }}(\text { Kwh } / \text { year }) \cdot \operatorname{Value}(\$ / \text { kWh })-C_{\text {O\&M }}(\$ / \text { year })\right)}$

These technical indicators shown in Eqns. 5, 7 and 8 and economic indicators shown in Eqns. 11 and 12 are the performance indicators usually used for determining the viability of renewable energy systems.

\section{DETAILS OF THE GRID- CONNECTED PV SYSTEM UNDER INVESTIGATION}

\section{A. The grid-connected PV system}

Figure 7 shows the complete system which consists of 4764 unit of PV modules. The PV modules are mono crystalline, manufactured by SunPower. Its maximum efficiency reaches $16.9 \%$ at STC and falls to $14.5 \%$ due the temperature effect in summer in Qassim region, the complete electrical data are shown in Table 1. The PV array is divided into four groups, each group connected to one inverter of $250 \mathrm{~kW}$ equipped with MPPT system manufactured by China power, its maximum efficiency reaches to $97.7 \%$ as shown in Figure 8 [21] . In addition to that, one step-up transformer is used for connecting to grid. The miscellaneous and power conditioning losses are estimated to be $2.0 \%$ and $1.5 \%$ respectively. All PV modules are groundmounted, tilt angle equals to location latitude $\left(26.3^{\circ}\right)$ and azimuth angle equals zero. The area of land needed for installation the complete system is estimated at $11,000 \mathrm{~m}^{2}$ according to [19].

Table 1. Electrical Data of PV module SPR-210-

\begin{tabular}{|c|c|c|}
\hline \multicolumn{3}{|c|}{ BLK [20] } \\
\hline Peak Power (+/-5\%) & $\mathbf{P}_{\max }$ & $210 \mathrm{~W}$ \\
\hline Rated Voltage & $\mathrm{V}_{\mathrm{mp}}$ & $40.0 \mathrm{~V}$ \\
\hline Rated Current & $\mathrm{I}_{\mathrm{mp}}$ & $5.25 \mathrm{~A}$ \\
\hline Open Circuit Voltage & $\mathrm{V}_{\text {oc }}$ & $47.7 \mathrm{~V}$ \\
\hline Short Circuit Current & $\mathrm{I}_{\mathrm{sc}}$ & $5.75 \mathrm{~A}$ \\
\hline Efficiency & & $16.9 \%$ \\
\hline Temperature Coefficient & & $-0.38 \%$ \\
\hline
\end{tabular}

\section{B. Location and weather data}

The suggested location is near Qassim University at Longitude $43.75^{\circ} \mathrm{E}$ and Latitude $26.35^{\circ} \mathrm{N}$. The weather and solar irradiance data are recorded for one year by a meteorological station located in Qassim University for period 6/1/ 2013 $5 / 1 / 2015$. The weather and solar irradiance data calculated from one minute recorded values are shown in appendix. The annual average irradiance of recorded readings is in good agreement with previously reported data shown in Figure 2, which makes these recent readings more reliable.

\section{Financial and economic data}

This study focuses on the investment cost of solar PV power plants. This includes costs for PV modules and inverters as well as the Balance of System cost (BOS) which includes: installation, mounting, DC cabling, switch gear, grid connection, transformer, infrastructure development, planning and documentation.

The current international price of $\mathrm{PV}$ modules for mono-si type is between (0.56-0.67) $\$ / \mathrm{Wp}$ as stated by the Energy trend website [22], while the international price of inverters is between $(0.11-0.13) \$ / \mathrm{Wp}$ as stated in the recent report prepared by Fraunhofer-Institute for Solar Energy Systems for Current and Future Cost of Photovoltaics [3]. In this study, the highest price will be chosen to be in safe side for both PV modules and inverters. The BOS cost and O\&M cost as estimated in the report prepared by FraunhoferInstitute for Solar Energy Systems (ISE) for Current and Future Cost of Photovoltaics [3]. The considered costs are illustrated in Table 2. The interest and inflation rates are $2 \%$ and $2.2 \%$ respectively as published by SAMA on its website [8]. and the discount rate is estimated at $4.5 \%$. In this study we assume no debt as a part of the capital cost, the life period of project is 25 years which is equal to the life cycle of PV modules. The life period of inverters is 15 years and the salvage value is $20 \%$ of capital cost.

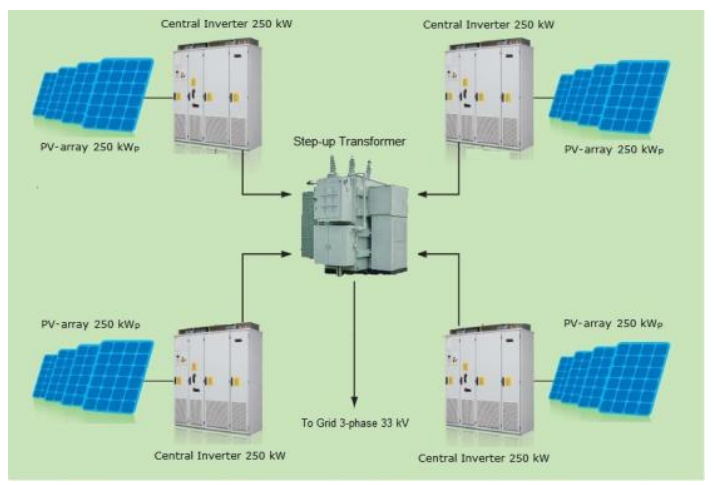

Fig. 7: Complete PV grid-connected system 


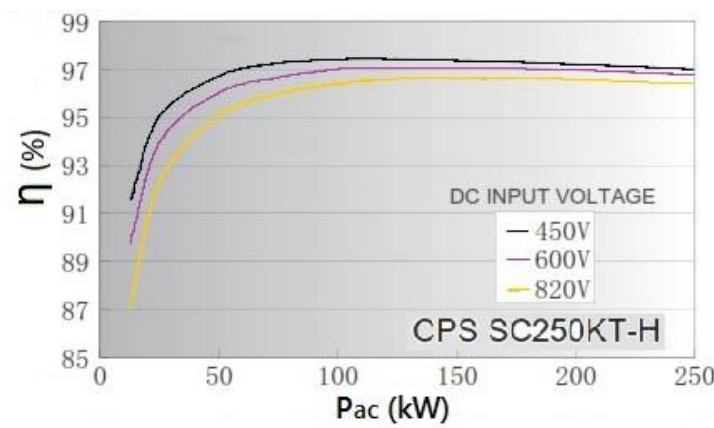

Fig. 8: Variation of Inverter's efficiency with loading

Table 2. Details of BOS and O\&M costs[3]

\begin{tabular}{lll}
\hline installation & $\mathbf{5 5}$ & $\$ / \mathrm{kW}_{\mathrm{p}}$ \\
mounting & 82.5 & $\$ / \mathrm{kW}_{\mathrm{p}}$ \\
\hline DC cabling & 55 & $\$ / \mathrm{kW}_{\mathrm{p}}$ \\
\hline switch gear & 5.5 & $\$ / \mathrm{kW}_{\mathrm{p}}$ \\
\hline grid connection & 66 & $\$ / \mathrm{kW}_{\mathrm{p}}$ \\
transformer & 22 & $\$ / \mathrm{kW}_{\mathrm{p}}$ \\
\hline infrastructure & 44 & $\$ / \mathrm{kW}_{\mathrm{p}}$ \\
\hline Planning \& doc. & 38.5 & $\$ / \mathrm{kW}_{\mathrm{p}}$ \\
\hline O\&M & 22 & $\$ / \mathrm{kW}_{\mathrm{p}} / \mathrm{yr}$ \\
\hline
\end{tabular}

\section{RESULTS AND DISCUSSION}

\section{A. Technical analysis}

The simulation results show that, the total energy injected to the grid is $2025.6 \mathrm{MWh} /$ year as shown in Table 3 . Figure 9 shows the average monthly energy supplied to the grid. The total energy supplied to the grid during the life time of project (25 years) is $42978.9 \mathrm{MWh}$ assuming the energy yield decreases by $1 \%$ annually due to degradation in the rated output power of $\mathrm{PV}$ modules.

The annual YF is 2024.7, this means that the PV system in this location under this weather condition can produce its rated power for 2024.7 times during one year. The monthly YF is in the range from 153.73 to 184.52 as shown in Figure 10. The YF of system under investigation is considered high comparing with similar PV grid-connected systems worldwide, for example; 1163 in Ghana[13], 1696.6 in Oman [16], 1861-1922.7 in Kuwait [7], 400-1300 in Germany, 450-1400 in Italy and 470-1230 in Japan [14].

$\mathrm{CF}$ For the system under investigation is 23.1\%. This value of $\mathrm{CF}$ is reasonable comparing with similar PV grid-connected systems worldwide, for example; 13.2 in Ghana [13], 19.64 in Oman [16], 21.6-22.5 in Kuwait [7] and 14-24 in USA [23]. The annual PR for the PV system under investigation is $84.27 \%$ and monthly PR in the range from $80.26 \%$ to $89.11 \%$ as shown in Figure 11 .
Over the last 20 years, the performance ratio of a new PV installation has improved from $65 \%$ to approximately $85 \%$, this improvement is due to more precise module rating, better design and installation, and more reliable components [24]. Performance ratio values have evolved from $50 \%$ to $75 \%$ in late 1980 s, via $70-80 \%$ in 1990 s, to $>80 \%$ nowadays, with some systems reaching $90 \%$ [25].

Table 3. Summary results of performance indicators.

\begin{tabular}{|c|c|c|}
\hline Annual Energy yield & 2025.6 & MWh \\
\hline Annual capacity factor & 23.1 & $\%$ \\
\hline Annual yield factor & 2024.7 & \\
\hline Annual performance ratio & 84.27 & $\%$ \\
\hline Levelized cost of energy & 0.0359 & $\$ / \mathrm{kWh}$ \\
\hline Simple payback time & 13.7 & year \\
\hline $\begin{array}{l}\text { Annual GHG emission } \\
\text { reduction }\end{array}$ & 1755 & $\mathrm{tCO}_{2}$ \\
\hline
\end{tabular}

\section{B. Economic Analysis}

The LCOE calculation is done in actual prices of the reference year 2015 for PV modules according to Energy trend website[22], and 2014 for other BOS components are according to the report prepared by Fraunhofer-Institute for Solar Energy Systems [3]. The LCOE for the system under investigation is $0.0359 \$ / \mathrm{kWh}$. This value is encouraging value in comparison to other reported values in 2015 in some different countries, for example; .051-.09 in Brazil, .053-.09 in China, $.061-0.1$ in France, .051- .069 in Morocco, .049.076 in Spain and .047-.076 in USA [3]. It is worth to mention that the method of LCOE is suitable to compare the cost of energy produced in PV systems of different generation and cost structures. But it is not suitable for determining the financial viability of a specific PV system. For that, a financing calculation must be done taking into account all revenues and expenditures on the basis of a cash flow model

The SPBT depends on the price of exported electricity to the grid, for the system under investigation it is 13.7 years on the base of 0.0533 $\$ / \mathrm{kWh}$ which is equivalent to the new tariff of electricity in Saudi Arabia for residential sector.

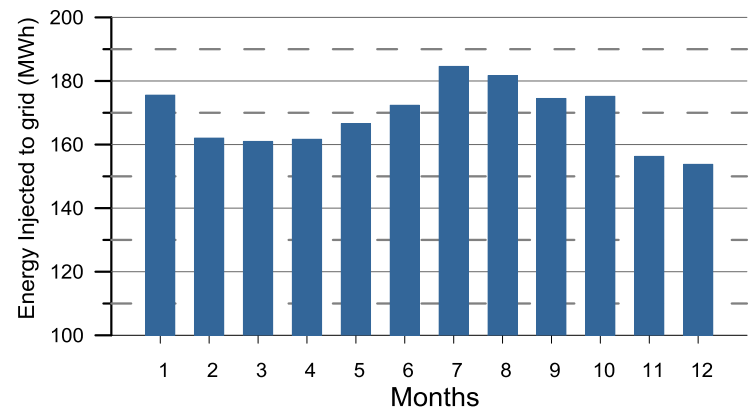

Fig. 9: Monthly average of energy injected to grid 


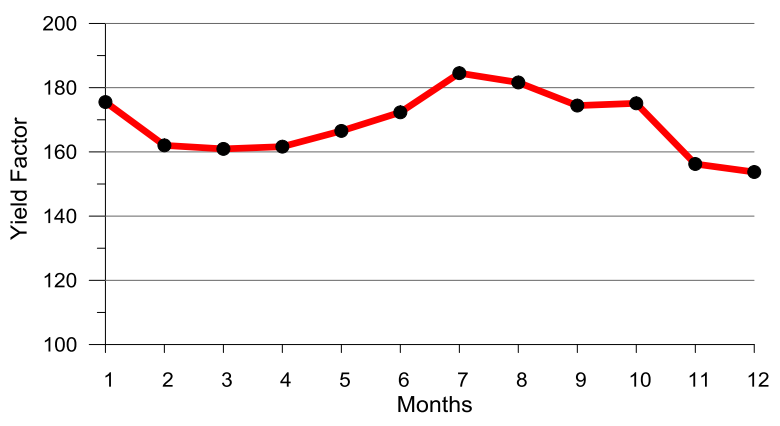

Fig. 10: Monthly Yield Factor, YF

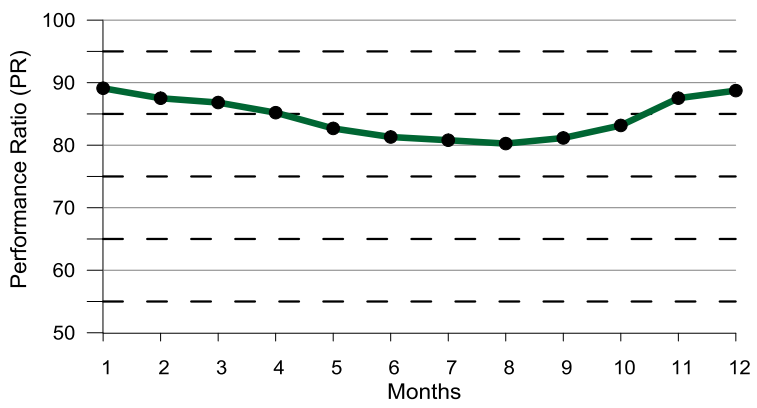

Fig. 11: Monthly Performance Ratio, PR

\section{Environmental effect}

As a result of utilization the system under investigation in Qassim region, the estimated greenhouse gas GHG emission reduction is about 1755 tons of $\mathrm{CO}_{2}$ annually. This quantity of GHG emission is equivalent to 4080 barrels of crude oil, or 754,137 liters of gasoline could be saved from burning for energy production annually, or equivalent to 161 Hectares of forest for absorbing the emitted $\mathrm{CO}_{2}$.

\section{CONCLUSION}

In this paper, a feasibility study has been performed for a 1MW PV grid-connected system in Qassim region in the middle of Saudi Arabia depending on real solar irradiance data. The simulation results showed high energy productivity and the performance indicators; Yield factor, Capacity factor and Performance ratio are high comparing with similar systems in some different countries. Economic analysis has been done using the LCOE and SPBT as the two most important economic indicators. The LCOE was $0.0359 \$ / \mathrm{kWh}$ which is less than the electricity tariff in Saudi Arabia. The SPBT was 13.7 years if the electricity sold with an export rate of $0.0533 \$ / \mathrm{kWh}$ which is equal to the tariff of electricity in Saudi Arabia for residential sector. Also the GHG emission reduction has been estimated at 1755 tons of $\mathrm{CO}_{2}$ annually. The prices of PV modules and other components of BOS are according to prices of year 2015. This study was done supposing that there is no any governmental incentives or grants which could make big difference.

In light of the positive results of this study, there are three crucial requirements for the progress of PV competitiveness in Saudi Arabia: The creation of a comprehensive series of laws and regulations providing the basis for renewable systems feeding into the public network, development of feed-intariff mechanism and providing good incentive for renewable systems through greenhouse gas abatement.

The final and most important conclusion derived from the study presented here is that the Saudi Arabia market possesses huge potential for investment in solar energy application.

\section{ACKNOWLEDGEMENTS}

The author would like to express the sincere appreciation to the staff of King Abdullah City for Atomic and Renewable Energy (K.A.CARE) for Facilitating access to the required data and their continuing support

\section{REFERENCES}

[1]. Eltawil M, Zhao Z. "Grid-connected photovoltaic power systems: technical and potential problems-A review", Renewable and Sustainable Energy Reviews 14 (2010) 112-129. doi:10.1016/j.rser.2009.07.015

[2]. T. Khatib, “A review of designing, installing and evaluating standalone photovoltaic power systems", Journal of Applied Sciences, 2010, vol. 10, no. 13, pp. 1212-1228. doi:10.3923/jas.2010.1212.1228 .

[3]. Fraunhofer ISE, Current and Future Cost of Photovoltaics. Long-term Scenarios for Market Development, System Prices and LCOE of Utility-Scale PV Systems. Study on behalf of Agora Energiewende. 2015. http://www.euractiv.com/files/euractiv_agora _solar_pv_study.pdf

[4]. Al-Qassim Region, Wikipedia, https://en.wikipedia.org/wiki/Al-

Qassim_Region\#Climate

[5]. Erica Zell, Sami Gasim, Stephen Wilcox, Suzan Katamoura, Thomas Stoff el, Husain Shibli, Jill Engel-Cox and Madi Al Subie, "Assessment of solar radiation resources in Saudi Arabia", Solar Energy 119 (2015) 422438. doi:10.1016/j.solener.2015.06.031

[6]. GIS Data Solar Radiation Maps, http://solargis.info/doc/free-solar-radiationmaps-DNI

[7]. Ali Hajiah, Tamer Khatib, K. Sopian, and M. Sebzali, "Performance of Grid-Connected Photovoltaic Systemin Two Sites in Kuwait", Hindawi Publishing Corporation International 
Journal of Photoenergy Volume 2012, Article ID 178175. doi:10.1155/2012/178175

[8]. Saudi Arabian Monetary Agency (SAMA), http://www.sama.gov.sa/en-

/Pages/default.aspx

[9]. Soteris A. Kalogirou, "Solar Energy Engineering-Processes and Systems",1st ed, 2009, Elsevier Inc.

[10]. D. L. Evans, "Simplified Method for Predicting Photovoltaic Array Output", Solar Energy, 1981, 27,6, 555-560. doi:10.1016/0038-092X(81)90051-7

[11]. RETScreen, Photovoltaic Project Analysis e-Textbook, Natural Resources Canada 2001 -2004 at:

http://www.retscreen.net/ang/textbook_pv.ht $\mathrm{ml}$

[12]. E. Kymakis, S. Kalykakis, and T. M. Papazoglou, "Performance analysis of a grid connected photovoltaic park on the island of crete," Energy Conversion and Management, 2009, vol. 50, no.3, pp. 433-438. doi:10.1016/j.enconman.2008.12.009

[13]. Ebenezer N. Kumi and A. Brew-Hammond, "Design and Analysis of a 1MW GridConnected Solar PV System in Ghana", African Technology Policy Studies Network, 2013, ATPS working paper No. 78. http://www.atpsnet.org/Files/rps27.pdf

[14]. McEvoy A, Markvart T, Castaner L. "Practical Handbook of Photovoltaics: Fundamentals and Applications", Elsevier; 2011, New York, USA.

[15]. B. Marion, J. Adelstein, K. Boyle , H. Hayden, B. Hammond, T. Fletcher, B. Canada, D. Narang, D. Shugar, H. Wenger, A. Kimber, L. Mitchell, G. Rich and T. Townsend, " Performance Parameters for Grid-Connected PV Systems " The proceedings of the 31st IEEE Photovoltaics Specialists Conference and Exhibition Lake Buena Vista, Florida January 3-7, 2005.

[16]. Hussein A. Kazem, Tamer Khatib,"Technoeconomical assessment of grid connected photovoltaic power systems productivity in Sohar, Oman", Sustainable Energy Technologies and Assessments 3 (2013) 6165. doi:10.1016/j.seta.2013.06.002

[17]. Holt, Thomas, Packey, Daniel J., and Short, Walter, "A Manual for the Economic Evaluation of Energy Efficiency and Renewable Energy Technologies", NREL, TP-462-5173 March 1995. http://www.nrel.gov/docs/legosti/old/5173.pdf

[18]. Benjamin S. Rashford, Natalie Macsalka, and Milton Geiger, "Renewable Energy Investment Analysis: What's the
PAYBACK?", University of Wyoming Extension publications, B-1235, June 2013 http://www.wyomingextension.org/agpubs/pu bs/B1235.pdf

[19]. Antonio L. and Steven H. "Hand book of Photovoltaic Science and Engineering", $2^{\text {nd }}$ edition, WILEY, 2012.

[20]. Data sheet of PV module (SPR-210-BLK): http://www.rectifier.co.za/Solar/sunpower/pdf /sunpower.pdf

[21]. Data sheet of Inverter: http://www.astronergy.com/attch/product/100 KW-1MW\%20inverter.pdf

[22]. Energy Trend: http://pv.energytrend.com/

[23]. Kristen Ardani and Robert Margolis,"The 2010 Solar Market Trends Report", NREL, 2010. http://www.nrel.gov/docs/fy12osti/51847.pdf

[24]. Achim Woyte, Mauricio Richter, David Moser, Stefan Mau, Nils Reich and Ulrike Jahn "Monitoring of Photovoltaic Systems: Good Practices And Systematic Analysis", Proceedings of the 28th European PV solar energy conference, Paris, France, 2013. https://www.ise.fraunhofer.de/de/veroeffentlic hungen/konferenzbeitraege/konferenzbeitraeg e-2013/28th-eupvsec/woyte.pdf

[25]. Wilfried van Sark, Nils Holger Reich, Björn Müller and Christian Reise,"Review of PV performance ratio development", proceedings of World Renewable Energy Forum,(WREF 2012), Volume 6, Denver, May 2012. doi: $10.13140 / 2.1 .2138 .7204$ 

ISSN : 2248-9622, Vol. 7, Issue 4, ( Part -1) April 2017, pp.09-17

\section{Appendix}

Monthly mean daily weather data and solar irradiance values calculated from one minute recorded values.

\begin{tabular}{cccccccc}
\hline Month & $\begin{array}{c}\text { Ambient } \\
\text { Temp. }\end{array}$ & $\begin{array}{c}\text { Relative } \\
\text { humidity }\end{array}$ & $\begin{array}{c}\text { Global } \\
\text { radiation } \\
\text { (horizontal) }\end{array}$ & $\begin{array}{c}\text { Global } \\
\text { radiation } \\
\text { (Tilted) }\end{array}$ & $\begin{array}{c}\text { Atm. } \\
\text { pressure }\end{array}$ & $\begin{array}{c}\text { Wind } \\
\text { speed }\end{array}$ & $\begin{array}{c}\text { Clearness } \\
\text { Index }\left(\mathrm{K}_{\mathrm{t}}\right)\end{array}$ \\
\hline January & ${ }^{\circ} \mathrm{C}$ & $\%$ & $\mathrm{kWh} / \mathrm{m}^{2} / \mathrm{d}$ & $\mathrm{kWh} / \mathrm{m}^{2} / \mathrm{d}$ & $\mathrm{kPa}$ & $\mathrm{m} / \mathrm{s}$ & \\
February & 14.2 & 44.6 & 4.30 & 5.82 & 94.2 & 2.4 & 0.66 \\
\hline March & 17.0 & 30.8 & 5.43 & 6.77 & 93.9 & 2.6 & 0.65 \\
\hline April & 21.9 & 33.8 & 6.07 & 6.70 & 93.7 & 2.5 & 0.58 \\
May & 28.2 & 22.1 & 5.95 & 5.89 & 93.7 & 2.9 & 0.61 \\
\hline June & 31.9 & 15.5 & 7.03 & 6.47 & 93.5 & 2.7 & 0.64 \\
\hline July & 34.3 & 11.2 & 8.18 & 7.18 & 93.1 & 2.7 & 0.72 \\
August & 36.2 & 11.1 & 8.16 & 7.29 & 92.9 & 2.6 & 0.75 \\
\hline September & 36.5 & 11.5 & 7.54 & 7.24 & 93.0 & 2.5 & 0.71 \\
October & 33.7 & 13.3 & 6.70 & 7.11 & 93.4 & 2.4 & 0.69 \\
\hline November & 28.0 & 19.3 & 5.67 & 6.79 & 93.8 & 2.7 & 0.66 \\
\hline December & 20.2 & 41.3 & 4.46 & 5.87 & 94.0 & 2.5 & 0.62 \\
\hline Annual (Avg) & 15.8 & 44.1 & 4.03 & 5.61 & 94.3 & 2.4 & 0.60 \\
\hline
\end{tabular}

